\title{
Interaction between foreign financial services and foreign direct investment in Transition Economies: An empirical analysis with focus on the manufacturing sector
}

\author{
Guido Cazzavillan ${ }^{\mathrm{a}}$, Krzysztof Olszewski ${ }^{\mathrm{b}, *}$ \\ ${ }^{a}$ University Ca' Foscari of Venice, Department of Economics, Cannaregio 873, Fondamenta S. Giobbe, 30121 Venezia, Italy \\ ${ }^{\mathrm{b}}$ National Bank of Poland, Świętokrzyska Street 11/21, 00-919 Warszawa, Poland
}

\section{A R T I C L E I N F O}

\section{Available online 6 September 2012}

Keywords:

Foreign direct investment

Financial services

Manufacturing sector

Bilateral stocks

Transition Economies

\begin{abstract}
A B S T R A C T
This paper studies the nexus between financial and non-financial foreign direct investment in Transition Economies, which are members of the EU. Three questions, which are pointed out in the theoretical literature, are discussed in the paper. We use a dataset for nine Transition Economies over the period 1996-2007, for most regressions we apply GMM and for one regression 2SLS. The empirical results lead to three important statements: non-financial FDI is positively affected by financial services FDI and by market potential. Foreign banks in the EU Transition Economies are mainly driven by non-financial FDI and the capital intensity of a country. FDI crowds out domestic investment in the manufacturing sector.
\end{abstract}

(c) 2012 University of Venice. Published by Elsevier Ltd. All rights reserved.

\section{Introduction}

Foreign direct investment and foreign banks are considered as an important source of economic growth and as a positive factor in the development and transformation of Transition Economies. The effect of foreign direct investment (FDI) and its short-run determinants are quite well studied, both in theoretical and empirical sense. However, a few studies about foreign financial services exist. Moreover, until now there has been only little empirical work which deals with the causality issue and answers the often discussed question:

Do foreign banks follow their clients or do foreign banks work as a catalyst for foreign direct investment in Transition Economies?

The theoretical as well as the empirical literature is concerned about the effects and determinants of the activity of foreign investors in Transition Economies. A positive growth effect of FDI trough backward knowledge spill-overs in Lithuanian firms was found by Smarzynska Javorcik (2004). The general effect of FDI on the whole economy is studied by Borensztein et al. (1998). They show that a sufficient high level of absorption capacity is a crucial condition for an economy to gain from the presence of FDI. The determinants of FDI in a gravity model approach are studied by Bevan and Estrin (2004) and Carstensen and Toubal (2004). Both find that market potential and risk have a strong effect on FDI. However, neither one of these two studies considers the role of foreign banks, which is a very important economic factor. A study by Mérö Valentinyi (2003) on the five largest EU Transition Economies shows the effect of foreign banks on the economy.

\footnotetext{
* Corresponding author.

E-mail address: krzysztof.olszewski@nbp.pl (K. Olszewski).
} 
Foreign banks contributed to the privatization and modernization of the banking sector. Another study on this topic, by Weill (2003) shows that foreign banks increase competition and lead to more efficiency in the banking sector. This leads to the question why foreign banks decide to enter Developing Economies. In comparison to the literature on FDI, relatively few studies exist on this topic. Goldberg and Johnson (1990) find that US banks follow their clients abroad. Contrary, Wezel (2004) does not find evidence for this hypothesis for the countries covered in our study. German banks indeed follow their clients when countries in Asia are considered. However, in Central and Eastern Europe the economic development is the main determinant for their entrance to the market. Further on, the recent empirical literature shows that foreign banks increase the efficiency of the local economy. Eller et al. (2006) use foreign banks as an important determinant of total factor productivity growth. Alfaro et al. (2004) find that the development of the local financial system crucially affects the positive effect of FDI on growth.

Data on FDI and foreign banks seems to show a pattern in Central and Eastern European Countries (CEEC): countries which have undergone a reform and allowed foreign banks to operate quite early, present also the highest FDI to GDP ratio in the past years. For example, by 2004 most of Hungarian banks were fully or partially owned by multinationals (Akbar and McBride, 2004). As reported by Buch (1997) the market share of foreign or joint-venture banks in total assets in 1995 was 22.7\% in Hungary, 15.9\% in Czech Republic and 4.4\% in Poland. Mérö and Valentinyi (2003) report data about foreign bank assets as \% of GDP. In the year 1998 and 2002 in Hungary the shares are 35.4\% and 49\%, 31.8\% and 94.4\% for the Czech Republic and $9.6 \%$ and $40.7 \%$ for Poland. In the same years the share of foreign banks in commercial bank assets was $62.5 \%$ and $90.7 \%$ for Hungary, $28.1 \%$ and $85.8 \%$ for the Czech Republic and $17.4 \%$ and $70.9 \%$ for Poland. The presence of foreign banks seems to be related to the FDI to GDP ratio in those countries. In 1995 Hungary received a considerable FDI inflow of $10 \%$ of GDP, which stayed at around $7 \%$ in the subsequent years (The World Bank, 2008). The Czech Republic received $4 \%$ and only $2 \%$ in the following years. A peak of $10 \%$ appeared in 1999 and the inflow remained quite high. Finally, Poland received around $2.6 \%$ and this number stayed constant, until it increased to $4.3 \%$ in 1999 and stayed at this level. The average FDI inflow over the period 1995-2005 was 6.57\% in Hungary, 5.94\% in the Czech republic and 3.42\% in Poland.

Those numbers do not allow for conclusions, however they indicate that an early opening to foreign banks and their participation in the economy was followed by a significant inflow of FDI. It is possible that various economic factors have triggered both kinds of FDI with different lag. An empirical study is necessary to find the exact relationship and causality. Basing on the recent literature, we formalize the following questions, which we answer by empirical evidence:

Do foreign banks work as a catalyst for FDI?

Do foreign banks follow their clients or open new markets?

What is the effect of FDI and foreign banks on domestic investment in the manufacturing sector?

Three different but strictly connected problems are tackled in this paper. The literature review on each of the topics is presented in the corresponding section.

The data used in this paper and the time period covered is as follows. The CEEC destination countries are Bulgaria (1999-2007), Czech Republic (1997-2006), Estonia (1997-2007), Hungary (1998-2006), Latvia (1996-2007), Lithuania (1995-2007), Poland (1996-2006), Slovak Republic (1996-2005) and Slovenia (1994-2006). Data availability allows to study the period presented in brackets. Moreover, we exclude the years of the global financial crisis, because it distorted the long-run relationship between FDI, foreign banks, domestic investment and economic growth in most countries. Romania is excluded due to data availability problems. Data on bilateral FDI stocks and stocks disaggregated by sectors origins from the Vienna Institute for International Studies. The data on financial services foreign direct investment (FSFDI) is reported at the NACE level. Financial services include banking, insurance, pension funds and leasing. The fraction of banking in the FSFDI stock is at least $80 \%$ in the case of Poland and up to 95\% in the case of Estonia (Eurostat, 2009). Foreign banks and other financial institutions which are usually subsidiaries ${ }^{1}$ of the same investor offer also the remaining financial services. Thus, foreign financial services can be called foreign banking activity. However, to be precise, we use the term financial services foreign direct investment (FSFDI) through this paper.

This paper is organized as follows. Section 2 deals with the determinants of foreign direct investment from donor countries to host countries. Section 3 deals with the determinants of foreign financial services. The nexus between foreign direct investment, foreign financial services and domestic investment in the manufacturing sector is presented in Section 4. Section 5 concludes. Data sources and the construction of the time series is explained in Appendix A, while the Stata commands applied in the regressions are presented in Appendix B.

\section{Determinants of bilateral FDI stocks}

A large and continuously growing stock of foreign direct investment can be observed in Transition Economies. Around 70-85\% of FDI in both the financial and non-financial sector origins from the following OECD countries: Austria, Belgium (and Luxembourg), Denmark, France, Germany, Italy, Japan, Korea, Netherlands, Portugal, Spain, UK and US. In order to

\footnotetext{
${ }^{1}$ For example, in Poland the bank Kredyt Bank and the insurance company Warta were owned by the KBC group; Allianz and ING offer banking and insurance; Moreover, PeKaO, the largest bank, offers banking and leasing. It is owned by UniCredit Banca.
} 
visualize the magnitude and the dynamics of the FDI stock in Transition Economies, we present data for Poland and for Slovenia. Poland is by far the largest economy in the group of Transition Economies studied in this paper. The highest inward FDI stock origins from Germany, followed by the Netherlands and Belgium and Luxembourg. Fig. 1 shows the development of bilateral FDI stocks and the aggregate FSFDI stock in Poland.

It is interesting to see the development in Slovenia, which has adopted a market economy very early and is now a member of the European Monetary Union. It also provides the longest time series of data. The development of the FDI and FSFDI stock in Slovenia is presented in Fig. 2. Austria is the main donor country of FDI, followed by France, Germany and the Netherlands. In both countries the FDI and FSFDI stock increases very much over time. For the other host countries, qualitatively a similar picture can be observed. FDI has a very high share in gross capital formation and a significant share of workers is employed by multinational companies (MNCs). However, only few advanced empirical studies on the long-run determinants of bilateral FDI stocks in Transition Economies exist. The determinants of the FDI stock in EU Transition Economies are studied at the bilateral level by Bevan and Estrin (2004). Their study is repeated by Carstensen and Toubal (2004) who take the endogeneity problem

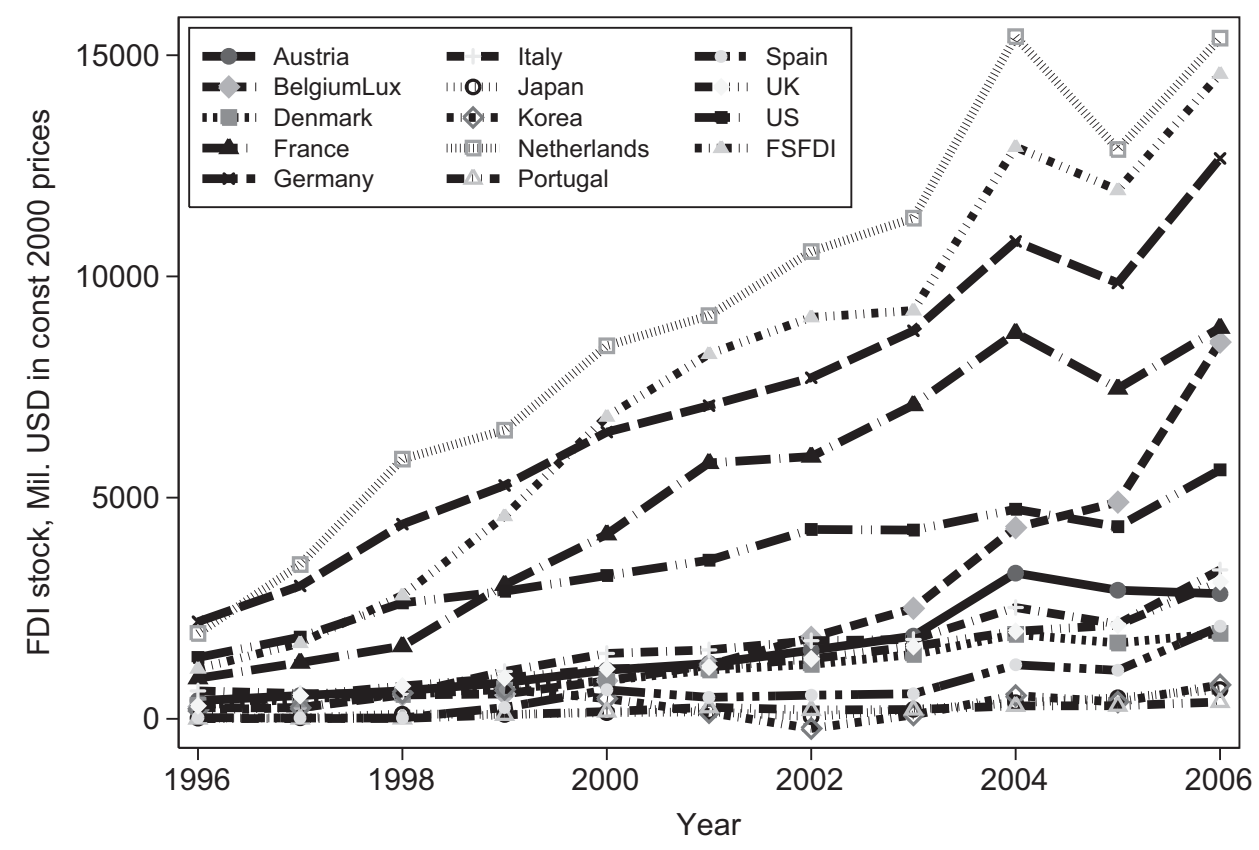

Fig. 1. Stock of FDI from 13 donor countries and total FSFDI stock in Poland.

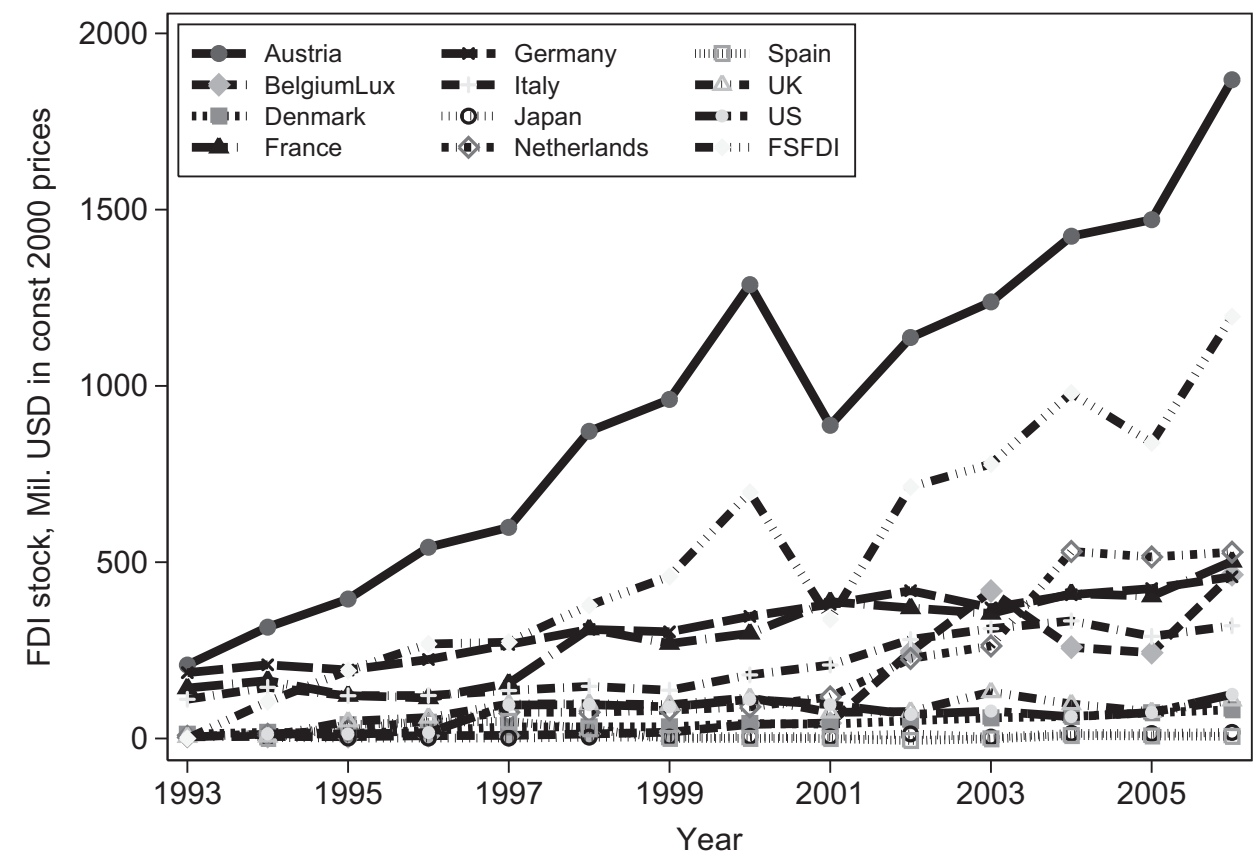

Fig. 2. Stock of FDI from 11 donor countries and total FSFDI stock in Slovenia. Portugal and South Korea do not report a stock. 
into account. Carstensen and Toubal (2004) perform a dynamic panel difference GMM regression on bilateral FDI stocks in seven Central and Eastern European Countries supplied by 10 OECD countries ${ }^{2}$ over the period 1993-1999. They find that the main determinants of FDI in Transition Economies are lagged FDI, market potential, skill ratio, private market share, the methods of privatization and relative capital endowments. Trade costs, relative unit labor costs and risk have a strong negative effect.

Among the few papers that base on a theoretical model are Barrell and Pain (1996). They set up and solve the profit maximization problem of a firm that can produce at home or abroad. The inputs in the production function are labor and physical capital, and for each market its optimal amount is calculated. This is a standard optimization problem with constraints, so we just summarize the baseline result. According to Barrell and Pain (1996) the optimal FDI stock is a function of demand, capital and labor costs in the host country and the donor country. A similar specification for the optimal FDI flow can be found in Mody et al. (2001). For our purposes we include the lagged FDI stock, because it affects the optimal amount of FDI stock in the current period and the optimal FDI stock can be described by the following function:

$$
\mathrm{FDI}_{t}^{*}=f\left(\mathrm{FDI}_{t-1}^{*}\right. \text {, market size, capital costs, labor costs, risks) }
$$

The application of a dynamic panel and usage of stocks in levels allows to see the long-run relationships and impacts of the variables of interest. We apply a modified version of the equation proposed by Carstensen and Toubal (2004). We include nine Transition Economies and 13 donor countries, moreover extend the period to 1996-2007. This allows us to make more general statements about the long-run dynamics of the stocks. Moreover, we include financial services FDI. Relative unit labor costs are rising in Transition Economies and thus a well-functioning and competitive capital market is of high importance to FDI inflow, as Akbar and McBride (2004) state. We consider this fact in our study. FDI denotes the stock of foreign direct investment excluding financial services. FSFDI is the stock of foreign direct investment in the financial services sector. The index $i$ denotes the host country, $j$ denotes the donor country and $t$ is the time index. The bilateral FDI stock is described by the following equation:

$$
\mathrm{FDI}_{i j t}=\alpha \mathrm{FDI}_{i j t-1}+\beta_{1} \mathrm{FSFDI}_{i j t}+\beta_{2} \mathrm{MKP}_{i t}+\beta_{3} \mathrm{RGDP}_{i j t}+\beta_{4} \mathrm{RKL}_{i j t}+\beta_{5} \mathrm{INTSPREAD}_{i t}+\beta_{6} \mathrm{RISK}_{i t}+\mu_{i j}+v_{i j t}
$$

The lagged dependent variable $\operatorname{FDI}_{i j t-1}$ enters the regression with the parameter $\alpha(|\alpha|<1)$, which represents its persistence. MKP stands for market potential of the host country. It is the sum of its GDP and the GDPs of the other Transition Economies, which are divided by the road distance between the capitals. Most of FDI is assumed to be of horizontal nature (Neuhaus, 2006), but a fraction is used to serve the surrounding market. GDP and market potential cannot be included in the same regression. Even if market potential is measured excluding the GDP of the host country these variables are collinear. Therefore, GDP is included in MKP and not estimated separately. Also GDP per capita and GDP per worker are collinear to MKP thus are not included in the regressions. RKL measures relative capital intensity per worker, which is proxied by the investment to worker ratio. Different variables which capture the development and stability of the financial market and the economy are included. The interest rate spread (INTSPREAD) measures the risk of doing business and proxies the efficiency of banks. The less efficient banks are, the higher their margin is. Moreover, the spread includes the risk premium. M2RES is the ratio of M2 money to reserves and it is a good indicator for crisis risk. All \$ variables are divided by the number of workers. We apply logarithm to market potential, in order to capture its growth. We take first differences in order to make the data stationary and get rid of unobservable country specific effects. The equation is estimated with difference GMM and has the form

$$
\begin{aligned}
\Delta \mathrm{FDI}_{i j t}= & \alpha \Delta \mathrm{FDI}_{i j t-1}+\beta_{1} \Delta \mathrm{FSFDI}_{i t}+\beta_{2} \Delta \ln \mathrm{MKP}_{i t}+\beta_{3} \Delta \mathrm{RGDP}_{i j t} \\
& +\beta_{4} \Delta \mathrm{RKL}_{i j t}+\beta_{5} \Delta \mathrm{INTSPREAD}_{i t}+\beta_{6} \Delta \mathrm{RISK}_{i t}+\Delta v_{i j t}
\end{aligned}
$$

Data $^{3}$ on bilateral FDI stocks is available on total economy level. Stocks of financial services are reported only as total stocks in the host country and their origin is not specified. We have to simplify the regression and use FSFDI $i t$ instead of FSFDI $i j t$. The only change is the fact that we cannot determine the direct relationship between FSFDI and FDI from a specific donor country, but rather estimate how firms from different countries react to total FSFDI stock.

\subsection{Empirical results on the determinants of bilateral FDI stocks}

We apply a gravity model and run a Generalized Method of Moments regression to tackle the endogeneity problem. This econometric method is very often used in the recent literature. The GMM regression corrects the endogeneity bias and allows to determine causality between FDI and FSFDI. We present a very short description of the GMM method. ${ }^{4}$ The simplest specification of the dynamic panel is $y_{i j t}=\alpha y_{i j t-1}+\beta x_{i j t}+\epsilon_{i j t}$ with $|\alpha|<1$ and $\epsilon_{i j t}=\mu_{i j}+v_{i j t}$. The total error term $\epsilon_{i j t}$ is composed of an unobserved country-pair effect $\mu_{i j}$ and the error term $v_{i j t}$. Following Arellano and Bond (1991) we take first differences, thus the unobserved effect and the time trend disappears. When the explanatory variables are predetermined, we obtain the following moment conditions $E\left[x_{i j t-1} \Delta v_{i j s}\right]=0$ for $t \leq s$ and $E\left[y_{i j t-2} \Delta v_{i j s}\right]=0$ for $t \leq s$. Running

\footnotetext{
${ }^{2}$ In their study, the OECD countries are Austria, Belgium (including Luxembourg), Denmark, France, Italy, Germany, Portugal, Spain, UK and US. The CEEC destination countries are Bulgaria, Czech Republic, Hungary, Poland, Romania, Slovak Republic and Slovenia.

3 There is a huge interest in disaggregated bilateral data, as stated by the International Monetary Fund (http://www.imf.org/external/np/sta/cdis/ index.htm), but the work is still on-going.

${ }^{4}$ Roodman (2006), who is the author of the GMM implementation in Stata (xtabond2) which we apply, gives a theoretical and practical introduction to GMM. Another good introduction to applied GMM and other advanced dynamic panel data models is Baum (2006).
} 
Table 1

Short-run determinants of FDI. GMM regression. $z$-Statistic in brackets, bold=significant at 5\% level. Time trend included.

\begin{tabular}{|c|c|c|c|c|c|c|}
\hline Independent variables & $\begin{array}{l}(1) \\
\text { FDI }\end{array}$ & $\begin{array}{l}(2) \\
\text { FDI }\end{array}$ & $\begin{array}{l}(3) \\
\text { FDI }\end{array}$ & $\begin{array}{l}(4) \\
\text { FDI }\end{array}$ & $\begin{array}{l}(5) \\
\text { FDI }\end{array}$ & $\begin{array}{l}(6) \\
\text { FDI }\end{array}$ \\
\hline FDI_lag & $\begin{array}{l}\mathbf{0 . 6 9 5 1} \\
(18.09)\end{array}$ & $\begin{array}{l}\mathbf{0 . 7 1 2 5} \\
(18.93)\end{array}$ & $\begin{array}{l}\mathbf{0 . 6 9 6 0} \\
(18.97)\end{array}$ & $\begin{array}{l}\mathbf{0 . 7 1 6 7} \\
(18.48)\end{array}$ & $\begin{array}{l}\mathbf{0 . 7 2 7 5} \\
(19.79)\end{array}$ & $\begin{array}{l}\mathbf{0 . 7 1 0 7} \\
(17.76)\end{array}$ \\
\hline FSFDI & $\begin{array}{l}\mathbf{0 . 1 3 3 7} \\
(3.18)\end{array}$ & $\begin{array}{l}\mathbf{0 . 1 3 4 2} \\
(3.21)\end{array}$ & $\begin{array}{l}\mathbf{0 . 1 0 6 0} \\
(3.08)\end{array}$ & $\begin{array}{l}\mathbf{0 . 1 2 7 0} \\
(3.15)\end{array}$ & $\begin{array}{l}\mathbf{0 . 1 2 9 4} \\
(3.31)\end{array}$ & $\begin{array}{l}\mathbf{0 . 1 0 1 9} \\
(3.01)\end{array}$ \\
\hline MKP & $\begin{array}{l}\mathbf{2 1 0 0 . 5 4 3} \\
(2.70)\end{array}$ & $\begin{array}{l}\mathbf{2 3 7 0 . 8 7 7} \\
(2.89)\end{array}$ & $\begin{array}{l}\mathbf{1 4 7 1 . 4 0 8} \\
(2.14)\end{array}$ & $\begin{array}{l}\mathbf{3 3 1 4 . 4 5} \\
(3.49)\end{array}$ & $\begin{array}{l}\mathbf{3 4 6 2 . 6 4 3} \\
(3.58)\end{array}$ & $\begin{array}{l}\mathbf{2 6 2 1 . 7 3 1} \\
(3.15)\end{array}$ \\
\hline RKL & $\begin{array}{l}-47.21176 \\
(-0.31)\end{array}$ & $\begin{array}{l}-115.0385 \\
(-0.91)\end{array}$ & $\begin{array}{l}-22.9976 \\
(-0.18)\end{array}$ & $\begin{array}{l}-197.1445 \\
(-1.17)\end{array}$ & $\begin{array}{l}-228.6418 \\
(-1.68)\end{array}$ & $\begin{array}{l}-107.4878 \\
(-0.78)\end{array}$ \\
\hline RGDP & & & & $\begin{array}{l}\mathbf{9 1 3 . 6 1 4 9} \\
(2.19)\end{array}$ & $\begin{array}{l}660.6271 \\
(1.70)\end{array}$ & $\begin{array}{l}618.3289 \\
(1.66)\end{array}$ \\
\hline M2RES & & $\begin{array}{l}-\mathbf{7 4 . 6 9 2 4} \\
(-2.54)\end{array}$ & $\begin{array}{l}-\mathbf{7 8 . 7 1 5 7} \\
(-3.03)\end{array}$ & & $\begin{array}{l}-73.4994 \\
(-2.98)\end{array}$ & $\begin{array}{l}-70.3425 \\
(-3.13)\end{array}$ \\
\hline INTSPREAD & & & $\begin{array}{l}-13.8853 \\
(-1.16)\end{array}$ & & & $\begin{array}{l}-19.0520 \\
(-1.62)\end{array}$ \\
\hline N. obs & 822 & 822 & 794 & 822 & 822 & 794 \\
\hline N. groups & 102 & 102 & 102 & 102 & 102 & 102 \\
\hline Hansen test & 88.48 & 98.36 & 100.71 & 97.66 & 100.50 & 100.56 \\
\hline$p$-Value & 0.012 & 0.060 & 0.299 & 0.114 & 0.439 & 0.829 \\
\hline $\operatorname{AR}(1) p$-value & 0.027 & 0.026 & 0.019 & 0.027 & 0.026 & 0.019 \\
\hline $\operatorname{AR}(2) p$-value & 0.082 & 0.082 & 0.131 & 0.084 & 0.083 & 0.128 \\
\hline N. instruments & 66 & 84 & 101 & 88 & 106 & 123 \\
\hline LR multiplier & 3.28 & 3.48 & 3.28 & 3.53 & 3.67 & 3.45 \\
\hline
\end{tabular}

the gravity regression, we first replicate the specification used by Carstensen and Toubal (2004). We get very similar results, which are not reported. Only the coefficient $\alpha$ on the lagged dependent variable FDI $_{i j t-1}$ is around twice as large. This indicates that the FDI stock is more persistent in the recent periods than it was in the periods studied by Carstensen and Toubal (2004). Its present value depends to a large extent on its past value. The parameter $\alpha$, which takes values around 0.7 in the regressions, is used to calculate the long-run effects. The short-run effects of the explanatory variables are presented in Table 1. The long-run multiplier is calculated as $1 /(1-\alpha)$ and takes a value around 3.3. This means that in the long run a change of an explanatory variable has the impact reported in Table 1, multiplied by around 3.3.

FSFDI enters all specifications in a positive and highly significant way. The coefficient is estimated to be around 0.100.13. FSFDI is the total stock in a given country and is usually bigger than the bilateral FDI stock (see Figs. 1 and 2 ). Thus, the parameter appears small, while the effect is large. It shows that foreign financial services work as an important catalyst for non-financial FDI. Market potential growth enters all regressions in a highly significant way. This confirms that FDI is mostly of horizontal nature and also used to serve the surrounding countries' markets. Relative capital endowments do not have any effect, once we control for FSFDI. In a regression without FSFDI, which is not reported, RKL has a positive and significant impact. This goes in favor of the gravity model. The bigger the capital intensity discrepancy is, the more can a multinational company gain from its comparative advantage. However, once we control for the stability and efficiency of the financial market (which is strongly related to FSFDI) the differences play no more a significant role. In specification (2) we add the M2 money over reserves ratio which measures the risk of a crisis. The higher this ratio, the more risk the multinational company has to face. It has a strong negative effect on the FDI stock. In specification (3) we include the interest spread. As expected this variable has a negative sign, but it is insignificant. The spread measures the inefficiency of the banks and also the risk of doing business. Because MNCs can obtain financing through FSFDI, it does not play a significant role. In specification (4) we include the relative size of the donor country GDP to the host country GDP (RGDP). It has a significant and positive effect. The larger the donor economy is in relative terms, the more FDI it can supply to the host country. Different combinations of the explanatory variables are presented in specifications (5) and (6). The parameters do not change in a significant way, which means that the model is robust. We also include other risk measures and parameters like government consumption, corporate tax rate, exports and imports but they are insignificant. Those results are not reported. The education of workers and the share of telephone line subscribers are included as a proxy for the technology level. Again they are insignificant. Moreover, unit labor costs and relative unit labor costs do not have a significant impact. Most likely because they are rather stable over time and similar to those of the donor country (Fig. 3 ).

The long-run determinants, presented in Table 2, are calculated by multiplying the coefficient $\beta$ by the long-run multiplier $1 /(1-\alpha)$. For example, the long-run effect of FSFDI in specification $(1)$ is $1 /(1-\alpha) * \beta_{1}=1 /(1-0.7) * 0.1337=0.4387$. We apply the delta method to calculate the standard errors of the non-linear combination of two coefficients. ${ }^{5}$ The significance of the variables does not change in a noticeable way. It is straightforward to interpret the long-run effect of FSFDI, MKPD, RKL and RGDP. FSFDI and market potential grow over time. An one time increase leads to a permanent positive effect. Relative capital

\footnotetext{
${ }^{5}$ This is done with the Stata command nlcom.
} 


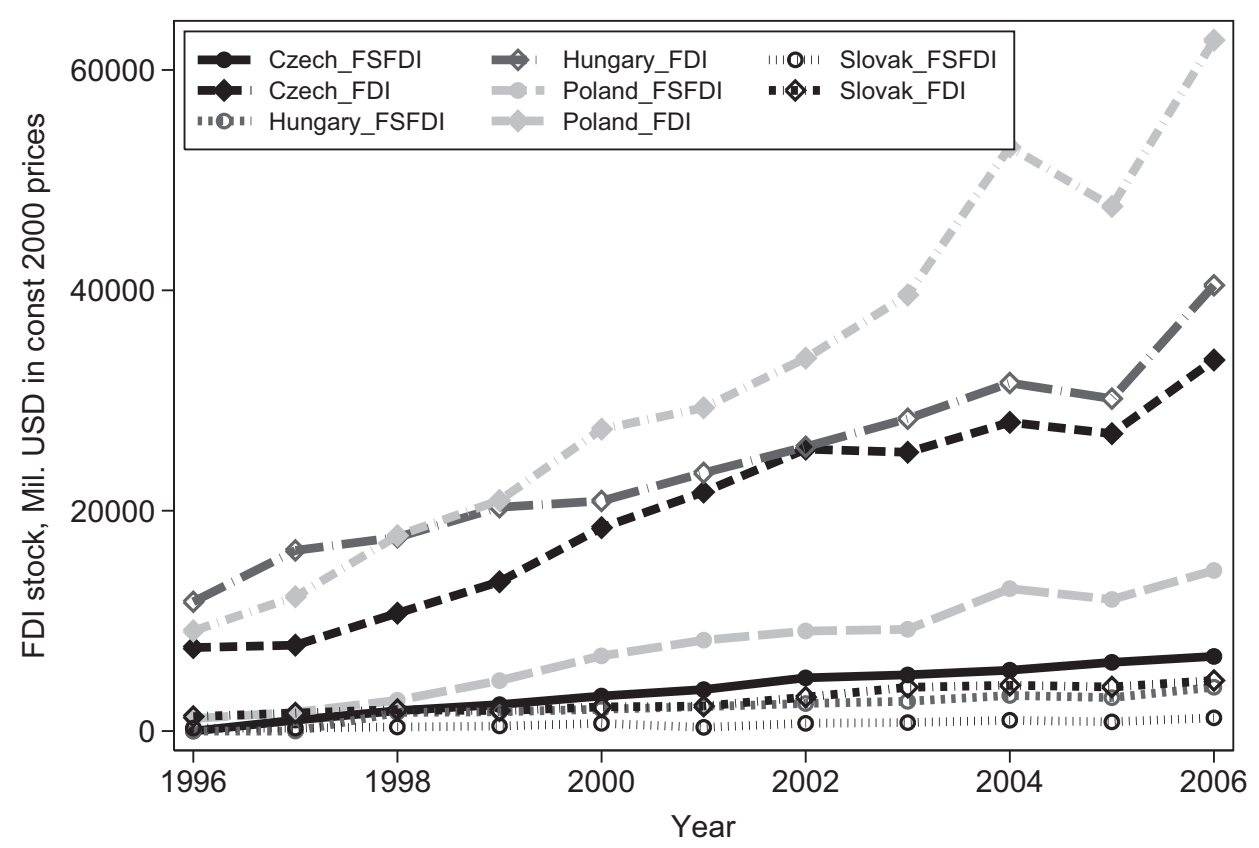

Fig. 3. Stock of FDI and FSFDI in the Czech Republic, Hungary, Poland and the Slovak Republic.

Table 2

Long-run determinants of FDI obtained from the GMM regression. $z$-Statistic in brackets, bold=significant at $5 \%$ level

\begin{tabular}{|c|c|c|c|c|c|c|}
\hline Independent variables & $\begin{array}{l}(1) \\
\text { FDI }\end{array}$ & $\begin{array}{l}(2) \\
\text { FDI }\end{array}$ & $\begin{array}{l}\text { (3) } \\
\text { FDI }\end{array}$ & $\begin{array}{l}(4) \\
\text { FDI }\end{array}$ & $\begin{array}{l}(5) \\
\text { FDI }\end{array}$ & $\begin{array}{l}(6) \\
\text { FDI }\end{array}$ \\
\hline FSFDI & $\begin{array}{l}\mathbf{0 . 4 3 8 7} \\
(4.39)\end{array}$ & $\begin{array}{l}\mathbf{0 . 4 6 7 1} \\
(4.34)\end{array}$ & $\begin{array}{l}\mathbf{0 . 3 4 8 9} \\
(4.4)\end{array}$ & $\begin{array}{l}\mathbf{0 . 4 4 8 7} \\
(4.38)\end{array}$ & $\begin{array}{l}\mathbf{0 . 4 7 4 9} \\
(4.57)\end{array}$ & $\begin{array}{l}\mathbf{0 . 3 5 2 4} \\
(4.50)\end{array}$ \\
\hline MKPD & $\begin{array}{l}\mathbf{6 8 9 1 . 4 5 2} \\
(2.53)\end{array}$ & $\begin{array}{l}\text { 8246.777 } \\
(2.66)\end{array}$ & $\begin{array}{l}4841.233 \\
(1.91)\end{array}$ & $\begin{array}{l}\mathbf{1 1 7 0 1 . 8 4 0} \\
(3.01)\end{array}$ & $\begin{array}{l}\mathbf{1 2 7 0 7 . 8 8 0} \\
(3.20)\end{array}$ & $\begin{array}{l}\mathbf{9 0 6 3 . 5 5 5} \\
(2.48)\end{array}$ \\
\hline RKL & $\begin{array}{l}-154.892 \\
(-0.31)\end{array}$ & $\begin{array}{l}-400.145 \\
(-0.92)\end{array}$ & $\begin{array}{l}-75.666 \\
(-0.18)\end{array}$ & $\begin{array}{l}-696.029 \\
(-1.18)\end{array}$ & $\begin{array}{l}-839.114 \\
(-1.72)\end{array}$ & $\begin{array}{l}-371.594 \\
(-0.79)\end{array}$ \\
\hline RGDP & & & & $\begin{array}{l}\mathbf{3 2 2 5 . 5 6 6} \\
(2.10)\end{array}$ & $\begin{array}{l}2424.497 \\
(1.69)\end{array}$ & $\begin{array}{l}2137.617 \\
(1.53)\end{array}$ \\
\hline M2RES & & $\begin{array}{l}-\mathbf{2 5 9 . 8 0 7 5} \\
(-2.56)\end{array}$ & $\begin{array}{l}-\mathbf{2 5 8 . 9 9 0 9} \\
(-3.12)\end{array}$ & & $\begin{array}{l}-\mathbf{2 6 9 . 7 4 2 6} \\
(-3.01)\end{array}$ & $\begin{array}{l}-\mathbf{2 4 3 . 1 8 0 2} \\
(-3.12)\end{array}$ \\
\hline INTSPREAD & & & $\begin{array}{l}-45.6855 \\
(-1.15)\end{array}$ & & & $\begin{array}{l}-65.8645 \\
(-1.55)\end{array}$ \\
\hline
\end{tabular}

endowments and GDP levels converge, thus their impact will diminish in the long run. However, the interest spread rate and the M2 money to reserves ratio do not show a clear pattern. One period's impact might be absorbed by a movement in the opposite direction in the next period.

The GMM specification ${ }^{6}$ is restricted to include up to two lags in order to keep the number of instruments lower than the number of groups. For all regressions we also apply a GMM specification in which the starting lag for the instrument is 2 and the longest lag is 4 . Another specification uses lags from 1 to 3 . In all cases only the number of instruments increases drastically. The estimation results do not change in a systematic way, which confirms the robustness of the model. These results are not presented. All GMM regressions are well specified, which is indicated by the Hansen test of overidentification and the Arellano-Bond test for first and second order autocorrelation. We always include a time trend, as recommended by Roodman (2006). Most of the stock variables have a time trend. ${ }^{7}$ FDI and FSFDI are stationary, once the time trend is accounted for.

The empirical results allow to conclude that foreign financial services are of highest importance to the bilateral FDI stock. Moreover, the FDI stock is persistent and depends to a large extent on its past period value. The market potential is very important, which indicates that FDI is mainly of horizontal nature and also used to serve the surrounding market. Further on, MNCs are exposed to the risk of an economic crisis and prefer to invest in countries which are less prone to it.

\footnotetext{
${ }^{6}$ The baseline regression specifications in Stata are presented in Appendix B. The descriptive statistics and correlation matrices of the variables in levels and in first differences for all regressions are presented in the working paper http://www.dse.unive.it/pubblicazioni/working-papers/2009/.

7 There is a highly significant negative time trend in the regression, which is around -100 . The time trend is only negative when market potential is included. This means that it leads to a too high FDI level and the time trend corrects it downwards.
} 


\section{Determinants of foreign financial services}

This section presents possible economic determinants of financial services FDI in Transition Economies. The empirical analysis shows to which extent banks follow their clients and whether they aim to serve the host market. An increasing stock of FSFDI can be observed over the last decade, on average. The following figure shows the stock of non-financial FDI and FSFDI in the four largest Transition Economies. The FDI stock is around five to ten times as large as the FSFDI stock. It is crucial to know what determines the very large and highly important activity of foreign financial services. Among many studies on the benefits of opening up for foreign banks are Buch (1997), Mérö Valentinyi (2003) and Akbar and McBride (2004). However, there are only a few recent empirical studies on the determinants of foreign banking activity in Central and Eastern European Transition Economies. Concerning banking activity in Developed and Developing Economies many empirical studies can be found. Buch (2000) as well as Jeanneau and Micu (2002) give a good overview of the literature and compare the methods used. A large share of papers deals with the assets of US, Japanese and German banks abroad. We present the results of two papers in more detail. Both deal with the question whether banks follow their clients abroad and come to different conclusions.

Goldberg and Johnson (1990) study the assets of foreign branches of US banks in 22 countries over the period 19721985. Total assets are affected by regulation, foreign direct investment, exports relative to GDP, population, GDP per capita, domestic deposits and exchange rate change. The authors state that the literature as well as some previous empirical results connect foreign bank activity with the follow-the-client hypothesis. Consequently, also trade is linked to foreign bank assets. The level of development is proxied by GDP per capita, while market potential is proxied by the population size. Domestic assets represent the activity of domestic banks, which have a negative effect on foreign banks. Foreign branches focus on wholesale banking and the study by Goldberg and Johnson deals with this kind of banking. Their empirical result seems to confirm that banks follow their clients. FDI has a positive and highly significant impact. Also trade and regulation affects foreign bank assets positively. Domestic assets and the level of development have a negative effect. Finally, potential market size and exchange rate fluctuations do not enter in a significant way. We conclude from their study that US banks were attracted by US firms operating abroad and by less developed economies in the 1970s and 1980s. In contrast to banks considered in their study, most of foreign banks in EU Transition Economies have a considerable share in retail banking. Wezel (2004) studies the determinants of the presence of German banks abroad. While for Asia he finds a very strong follow-the-client effect, for CEECs this effect is absent. Banks are strongly attracted by GDP per capita. Crisis risk, measured as M2 money over domestic reserves, has a strong negative effect.

In order to find the determinants of foreign banks in Transition Economies, we based on the specification proposed by Goldberg and Johnson (1990) and Wezel (2004), modify it and regress the following equation

$$
\begin{aligned}
\Delta \mathrm{FSFDI}_{i t}= & \alpha \Delta \mathrm{FSFDI}_{i t-1}+\beta_{1} \Delta \mathrm{FDI}_{i t}+\beta_{2} \Delta \mathrm{INV}_{i t}+\beta_{3} \Delta \mathrm{FREEDOM}_{i t} \\
& +\beta_{4} \Delta \mathrm{TAX}_{i t}+\beta_{5} \Delta \mathrm{INFLATION}_{i t}+\beta_{6} \Delta \mathrm{M}_{2} \mathrm{RES}_{i t}+\Delta v_{i t}
\end{aligned}
$$

We include the lagged dependent variable to obtain the long-run determinants. FSFDI depends on the non-financial FDI stock and total investment in a given year. This allows to state whether banks follow their clients or are directly involved in the host market. While many studies include GDP, we include investment. First, banks are directly connected to investment. Secondly, in the later part of this paper we focus on investment, therefore we use it here as a determinant of FSFDI. There is a strong collinearity between investment and GDP, thus only one measure of economic development can be used. The estimation results do not change very much, as investment takes a rather constant share of GDP. The index of economic freedom FREEDOM is included. ${ }^{8}$ This variable origins from the Heritage Foundation (2009) and measures how easily individuals can operate on the market. A free economy allows individuals to take most efficient decisions and allocate their effort in actions they consider as profitable. This increases the number of businesses and thus more potential clients for the foreign financial services exist. Further on, we include the corporate tax rate TAX. High taxes make a host country less attractive to foreign investors. Inflation which measures macroeconomic risk and M2 money over reserves, which measures the risk of a crisis are included. Moreover, we include the real interest rate REALINT and the development of the financial market FMKT. Financial market development is measured as the sum of stock market capitalization plus credits to the private sector divided by the GDP. Both variables can have a positive effect on the profitability of foreign financial services. To tackle the endogeneity between FSFDI, FDI and investment, we apply a 2SLS regression, using the XTIVREG2 code written by Schaffer (2007). We include FDI and investment lagged by one period as instruments. Moreover, lagged GDP, unit labor costs and share of exports to GDP are used as instruments. Lagging GDP solves the problem of strong correlation between GDP and investment in the same period. The stock of FSFDI follows a time trend and moreover, unobserved country effects can play a role. We therefore use the first differences regression to solve this problem. The error terms are robust to heteroskedasticity and autocorrelation. We expect the FDI variable to enter significantly. Investment, tax and country risk should play an important role, too. Contrary to the results obtained by Goldberg and Johnson (1990), we expect that economic development, measured by investment, has a strong positive effect. Investment should enter positively, as it requires different financial services and thus increases the countries' need for an advanced

\footnotetext{
${ }^{8}$ Disaggregated indicators of economic freedom cannot be applied for the considered countries. The freedom of banking, business and investment is nearly constant, thus by taking first differences these variables drop out.
} 
financial market. Foreign banks have a comparative advantage and can compete with domestic banks very well. In fact, foreign banks own former state banks and compete in the retail banking market. Moreover, the activities of foreign and domestic banks seem to converge as Weill (2003) states. This means that foreign banks serve to a large extent host country clients. On the other hand, domestic banks have to improve their business practices due to the increased competition.

\subsection{Empirics on the determinants of foreign financial services}

The regressions, presented in Table 3, show that the FSFDI stock does not depend on its past period value. This result is in line with the fact that FDI in financial services can move very quickly and is mainly determined by market parameters. Financial capital is very mobile compared to any other fixed capital. Moreover, as expected, FDI and investment positively affect the size of the FSFDI stock. In all specifications the stock of non-financial FDI has a very strong positive effect. The Stock-Yogo test for weak identification indicates that in all specifications the maximal IV relative bias is $5 \%$. Thus, all regressions and the choice of instruments can be considered as well specified. The results are presented in Table 3.

FDI enters the regression with very high significance, which means that foreign financial services follow their clients, or more general, they follow western clients to Transition Economies. Throughout all specifications investment has a significant effect on FSFDI. This means that foreign banks are not only following their clients but to a large extent also serve the host country market. Surprisingly, the index of economic freedom has no effect. This might result from the fact that it changes only little over time. The change of the tax rate does not have any effect, too. The tax rate declines in general, but is constant over many periods. In specification (2) we include two measures of macroeconomic risk, namely inflation and crisis risk, measured by the ratio of M2 money to reserves. Inflation enters with high significance, while crisis risk has no effect. The negative effect of inflation indicates that banks are afraid of loosing their loans due to a too high inflation. Crisis risk has no significant effect, because unlike FDI, FSFDI is very mobile and in case of an incoming crisis banks can shift capital from one market to another. In specification (3) the real interest rate is added to the base specification. The real interest rate directly affects the profit of banks. However, this variable just fails to be significant at the $10 \%$ level. The real interest rate differs significantly in levels among countries. Some countries, like Estonia and Latvia, show negative real interest rates. However, for most of the observations the interest rate is relatively stable. Finally, specification (4) captures the development of the financial market. This variable is the stock market capitalization plus credit to private sector divided by GDP. It does not enter in a significant way. This shows that the financial development is not a determinant of FSFDI. Following the literature, it seems that the development of the financial market is a result of the presence of foreign financial services and does not affect those in a significant way.

Table 3

Short-run determinants of FSFDI. 2SLS first differences regression (XTIVREG2) with heteroskedasticity and autocorrelation robust standard errors. Kleibergen-Paap $r k$ Wald $F$ weak identification test statistic and Stock-Yogo critical values for 5\% maximal IV bias and $10 \%$ and $15 \%$ relative size bias reported. $z$-Statistic in brackets, bold=significant at $5 \%$ level.

\begin{tabular}{|c|c|c|c|c|}
\hline Independent variables & $\begin{array}{l}\text { FSFDI } \\
(1)\end{array}$ & $\begin{array}{l}\text { FSFDI } \\
(2)\end{array}$ & $\begin{array}{l}\text { FSFDI } \\
(3)\end{array}$ & $\begin{array}{l}\text { FSFDI } \\
(4)\end{array}$ \\
\hline FSFDI_lag & $\begin{array}{l}0.2324 \\
(0.90)\end{array}$ & $\begin{array}{l}0.1982 \\
(0.87)\end{array}$ & $\begin{array}{l}0.2139 \\
(0.89)\end{array}$ & $\begin{array}{l}0.2413 \\
(0.90)\end{array}$ \\
\hline FDI & $\begin{array}{l}\mathbf{0 . 1 3 1 3} \\
(3.71)\end{array}$ & $\begin{array}{l}\mathbf{0 . 1 3 6 2} \\
(3.95)\end{array}$ & $\begin{array}{l}\mathbf{0 . 1 3 7 9} \\
(3.97)\end{array}$ & $\begin{array}{l}\mathbf{0 . 1 3 0 4} \\
(3.61)\end{array}$ \\
\hline INV & $\begin{array}{l}\mathbf{0 . 2 0 5 2} \\
(3.37)\end{array}$ & $\begin{array}{l}\mathbf{0 . 1 8 3 3} \\
(2.97)\end{array}$ & $\begin{array}{l}\mathbf{0 . 1 8 6 3} \\
(3.21)\end{array}$ & $\begin{array}{l}\mathbf{0 . 2 0 3 5} \\
(3.32)\end{array}$ \\
\hline FREEDOM & $\begin{array}{l}-13.7642 \\
(-0.63)\end{array}$ & $\begin{array}{l}-22.4501 \\
(-1.04)\end{array}$ & $\begin{array}{l}-15.4058 \\
(-0.73)\end{array}$ & $\begin{array}{l}-11.7058 \\
(-0.53)\end{array}$ \\
\hline TAX & $\begin{array}{l}-9.4361 \\
(-0.43)\end{array}$ & $\begin{array}{l}-19.0510 \\
(-0.82)\end{array}$ & $\begin{array}{l}-15.7533 \\
(-0.71)\end{array}$ & $\begin{array}{l}-11.6959 \\
(-0.53)\end{array}$ \\
\hline INFLATION & & $\begin{array}{l}-\mathbf{3 0 . 7 1 2 6} \\
(-2.06)\end{array}$ & & \\
\hline M2RES & & $\begin{array}{l}151.0707 \\
(1.16)\end{array}$ & & \\
\hline REALINT & & & $\begin{array}{l}21.2013 \\
(1.56)\end{array}$ & \\
\hline FMKT & & & & $\begin{array}{l}5.3370 \\
(1.00)\end{array}$ \\
\hline N. obs & 76 & 76 & 76 & 76 \\
\hline$R^{2}$ & 0.58 & 0.63 & 0.61 & 0.59 \\
\hline Weak ID test & 19.32 & 18.11 & 21.46 & 18.65 \\
\hline \multicolumn{5}{|l|}{ Stock-Yogo critical values } \\
\hline $5 \%$ max IV relative bias & 13.97 & 13.97 & 13.97 & 13.97 \\
\hline $10 \% \max$ IV size & 19.45 & 19.45 & 19.45 & 19.45 \\
\hline $15 \%$ max IV size & 11.22 & 11.22 & 11.22 & 11.22 \\
\hline
\end{tabular}


The estimation results show that FSFDI does not depend on its past value, is mainly affected by FDI and domestic investment. Financial services seem to follow to a large extent foreign clients. ${ }^{9}$ Domestic investment positively and significantly affects the FSFDI stock, which indicates that the host market is of importance. This is consistent with the findings of Wezel (2004). Crisis risk does not have any significant effect on FSFDI. The mobility of FSFDI makes it less prone to some risks, which hinder FDI.

\section{The nexus between FSFDI, FDI and domestic investment in manufacturing}

We finally analyze the nexus between FSFDI, FDI and domestic investment in manufacturing. The manufacturing sector attracts a large share of FDI and is important to the whole economy. On average 30\% of the FDI stock can be found in the manufacturing sector (Vienna Institute for International Studies, 2008a). Products from the manufacturing sector are used in the services sector or the trade sector. Tools of any kind produced by manufacturing firms serve in the construction sector. Moreover, the output of the manufacturing sector can be easily stored and exported or imported. Because of its importance, we focus in this section on the different industries in the manufacturing sector. Investigating the nexus of FDI, FSFDI and domestic investment, we focus on the DA-DN NACE classification manufacturing industries. ${ }^{10}$ This is the deepest disaggregation level for which all necessary data for all countries is available. The considered countries and timeperiods are as follows: Czech Republic (1996-2006), Estonia (2000-2007), Hungary (1998-2006), Lithuania (1995-2007), Poland (1995-2006), Slovak Republic (1995-2006) and Slovenia (1995-2007). For all countries but Estonia and Poland all industries are considered. For Estonia data is available only for industries DD, DF, DG, DH, DI, DJ and DK, while for Poland data on all industries but DC, DE and DN are present. We completely exclude Bulgaria and Latvia, because data on crucial variables like investment and FDI in industries is available for a very short period only. For all regressions we apply twostep difference GMM in order to tackle the endogeneity problem. The error terms are robust to heteroskedasticity and autocorrelation.

The impact of financial services and indicators of development of the financial market can have different effects on each industry. A better developed financial market serves all industries, in general. However, the more an industry depends on external finance, the higher this positive effect of financial services FDI will be. To capture this, the FSFDI are interacted with the dependence on external financing (DEF) of each industry. ${ }^{11}$ "External dependence is the fraction of capital expenditures not financed with cash flow from operations", as defined by Rajan and Zingales (1998, p. 567). Rajan and Zingales (1998) compute the dependence of different sectors on external financing for the US and argue that this pattern holds for any country in the world. Their variables are used by Guiso et al. (2004) to test the impact of financial development on growth in the EU. We interact the dependence variable with FSFDI and other financial variables in order to determine their effect on growth and investment in different sectors. The least dependent sector is DC, leather and leather products with an value equal to -0.14 . The highest dependence, 0.77 , is found in the electrical and optical equipment sector DL. Those values mean that leather producers create more cash-flow than they need for capital expenditures. Contrary, electrical equipment producers finance $77 \%$ of capital expenditures with external funds.

\subsection{Determinants of FDI in the manufacturing sector}

FDI in manufacturing is the stock of FDI in each of the DA-DN NACE classification manufacturing industries. The stock of FDI in each manufacturing industry is called FDIM. From now on, $i$ denotes the manufacturing industry, $j$ the host country and $t$ time. FDIM is regressed on its lagged value, because we expect that the past value has a significant effect on the current stock. The presence of MNCs in manufacturing as well as in any other sector of the economy is assumed to depend strongly on the presence of foreign banks. Their impact on the FDI stock in the whole economy is presented in Section 2. To account for different needs for external finance, we interact the foreign financial services stock with the dependence on external finance DEF. The value added (VA) in an industry can be seen as the main reason why the MNC operates in this industry. Further on, we investigate whether domestic investment in the same industry has any effect on the presence of FDI. MNCs gain from their comparative advantage, thus strong domestic investment should crowd out FDI. On the other hand, MNCs need intermediate goods in the production process and a branch of the literature argues that they enforce domestic investment. The effect of domestic investment is thus assumed to be ambiguous. One problem arises from the fact that we do not have any data on purely domestic investment in the manufacturing sector. Total investment, denoted INV, is the sum of foreign and domestic investment. FDIM is a stock and it is not easy to construct the flow from the stock. We take the first differences and neglect the depreciation of capital. Applying this procedure shows

\footnotetext{
${ }^{9}$ Unfortunately, the available data does not allow to state whether FSFDI is following other FDI from the same country and vice versa.

${ }^{10}$ The classification is: DA: food products, beverages and tobacco; DB: textiles and textile products; DC: leather and leather products; DD: wood and wood products; DE: pulp, paper, pap. products, publishing and printing; DF: cole, refined petrol. products and nuclear fuel; DG: chemicals, chemical products and man-made fibres; DH: rubber and plastic products; DI other non-metallic mineral products; DJ: basic metals and fabricated metal products, DK: machinery and equipment n.e.c.; DL: electrical and optical equipment; DM: transport; and DN: manufacturing n.e.c.

${ }^{11}$ We aggregated the data proposed by Rajan and Zingales (1998) to obtain values at the DA-DN level. For the DN sector we take the mean of all other sectors. The dependence on external financing is: DA 0.14, DN 0.4, DC - 0.14, DD 0.28, DE 0.18, DF 0.33, DG 0.25, DH 0.23, DI 0.06, DJ 0.24, DK 0.45, DL 0.77, DM 0.31, DN 0.27.
} 
that FDIM flows account for around 30\% of total investment. Thus, INV captures to a large part domestic investment. Beside these economic variables, also the corporate tax rate and risk measures are added. The risk measures are as before M2 money over reserves and inflation. The current FDI stock in manufacturing is described by the following equation:

$$
\begin{aligned}
\Delta \mathrm{FDIM}_{i j t}= & \alpha \Delta \mathrm{FDIM}_{i j t-1}+\beta_{1} \Delta \mathrm{FSFDI}_{j t} \times \mathrm{DEF}_{i}+\beta_{2} \Delta \mathrm{VA}_{i j t}+\beta_{3} \Delta \mathrm{INV}_{i j t} \\
& +\beta_{4} \Delta \mathrm{TAX}_{j t}+\beta_{5} \Delta \mathrm{INFLATION}_{i j t}+\beta_{6} \Delta \mathrm{M}_{2} \mathrm{RES}_{i j t}+\Delta v_{i j t}
\end{aligned}
$$

The regression results are presented in Table 4. In all specifications the Hansen test of over-identification and the Arellano Bond test for autocorrelation of the error term of the second order performs well. The number of instruments used is less than the number of groups. To keep the number of instruments low, we constrain the number of lags in the GMM regression to at most 2 . This constraint is applied to all GMM regressions in this paper. Secondly, only FDIM_lag, VA and INV are treated as endogenous variables. The other variables are treated as exogenous variables in the regression. A time trend is included, however it is always insignificant.

The baseline specification (1) includes all variables mentioned above. First and foremost, the lagged dependent variable, foreign financial services and value added enter with high significance. These results are robust to different specifications which include other variables. The dependance of FDI on its lagged value in manufacturing industries is similar to the case of all non-financial FDI studied in Section 2. This indicates that the persistence of FDI stock in the real economy is independent of the disaggregation level. The current value depends approximately with a parameter $\alpha=0.60$ on its past value. On average the long-run impact of the determinants presented above has to be multiplied by $1 /(1-\alpha)=2.5$ to obtain its long-run impact. The long run multiplier for each specification is presented in the last line of the results table. The increase of the FSFDI stock multiplied by the corresponding dependence on external finance increases the FDI stock in the same industry by a factor of around 0.11 . The increase in value added by one million international $\$$ in an industry increases the FDIM stock by 0.41 million \$. Throughout all specifications, inflation does not affect the FDIM stock. In specification (2) we include the capitalization of the stock-market interacted with the dependence on external finance. The stockmarket capitalization is a measure for the development of the host country's financial system and also a measure of general economic development. The stock market allows domestic firms to acquire capital and also measures how developed they are. When domestic firms grow, also the stock market grows. Because foreign firms gain from comparative advantage, thus from weak domestic firms, this variable enters significantly and negatively. The increase of the stock market capitalization by one million \$, multiplied by the DEF, decreases the FDIM stock by 0.031 million. The other variables do not change in a significant way. In specification (3) unit labor costs in relation to those in Austria are included.

Table 4

Short-run determinants of FDI in the manufacturing sector. Two-step difference GMM regression. $z$-Statistic in brackets, bold=significant at 5\% level.

\begin{tabular}{|c|c|c|c|c|c|}
\hline Independent variables & $\begin{array}{l}\text { FDIM } \\
(1)\end{array}$ & $\begin{array}{l}\text { FDIM } \\
(2)\end{array}$ & $\begin{array}{l}\text { FDIM } \\
(3)\end{array}$ & $\begin{array}{l}\text { FDIM } \\
(4)\end{array}$ & $\begin{array}{l}\text { FDIM } \\
(5)\end{array}$ \\
\hline FDIM_lag & $\begin{array}{l}\mathbf{0 . 5 9 9 1} \\
(6.82)\end{array}$ & $\begin{array}{l}\mathbf{0 . 5 6 2 8} \\
(3.53)\end{array}$ & $\begin{array}{l}\mathbf{0 . 6 0 0 0} \\
(6.88)\end{array}$ & $\begin{array}{l}\mathbf{0 . 5 9 6 1} \\
(6.71)\end{array}$ & $\begin{array}{l}\mathbf{0 . 5 6 1 8} \\
(4.07)\end{array}$ \\
\hline FSFDI $\times$ DEF & $\begin{array}{l}\mathbf{0 . 1 0 8 1} \\
(2.35)\end{array}$ & $\begin{array}{l}\mathbf{0 . 1 4 8 4} \\
(2.05)\end{array}$ & $\begin{array}{l}\mathbf{0 . 1 0 6 9} \\
(2.36)\end{array}$ & $\begin{array}{l}\mathbf{0 . 1 1 1 4} \\
(2.38)\end{array}$ & $\begin{array}{l}\mathbf{0 . 1 5 3 0} \\
(2.28)\end{array}$ \\
\hline VA & $\begin{array}{l}\mathbf{0 . 4 1 2 8} \\
(1.97)\end{array}$ & $\begin{array}{l}0.5848 \\
(1.71)\end{array}$ & $\begin{array}{l}\mathbf{0 . 4 1 0 7} \\
(1.95)\end{array}$ & $\begin{array}{l}\mathbf{0 . 4 1 6 1} \\
(1.97)\end{array}$ & $\begin{array}{l}\mathbf{0 . 5 9 1 7} \\
(1.86)\end{array}$ \\
\hline INV & $\begin{array}{l}-0.2611 \\
(-0.89)\end{array}$ & $\begin{array}{l}-0.0993 \\
(-0.32)\end{array}$ & $\begin{array}{l}-0.2642 \\
(-0.89)\end{array}$ & $\begin{array}{l}-0.2577 \\
(-0.87)\end{array}$ & $\begin{array}{l}-0.0864 \\
(-0.27)\end{array}$ \\
\hline TAX & $\begin{array}{l}0.0369 \\
(0.02)\end{array}$ & $\begin{array}{l}0.2035 \\
(0.11)\end{array}$ & $\begin{array}{l}0.0908 \\
(0.04)\end{array}$ & $\begin{array}{l}0.4941 \\
(0.23)\end{array}$ & $\begin{array}{l}0.6608 \\
(0.33)\end{array}$ \\
\hline INFLATION & $\begin{array}{l}-3.1936 \\
(-1.35)\end{array}$ & $\begin{array}{l}-2.7215 \\
(-0.93)\end{array}$ & $\begin{array}{l}-3.0843 \\
(-1.34)\end{array}$ & $\begin{array}{l}-3.2993 \\
(-1.37)\end{array}$ & $\begin{array}{l}-3.0262 \\
(-1.23)\end{array}$ \\
\hline M2RES & $\begin{array}{l}-11.3211 \\
(-0.96)\end{array}$ & $\begin{array}{l}-6.3529 \\
(-0.55)\end{array}$ & $\begin{array}{l}-10.9315 \\
(-0.99)\end{array}$ & $\begin{array}{l}-11.4530 \\
(-0.93)\end{array}$ & $\begin{array}{l}-6.0771 \\
(-0.51)\end{array}$ \\
\hline STKMKTCAP $\times$ DEF & & $\begin{array}{l}-\mathbf{0 . 0 3 1 0} \\
(-1.87)\end{array}$ & & & $\begin{array}{l}-\mathbf{0 . 0 3 1 5} \\
(-2.15)\end{array}$ \\
\hline ULCRA & & & $\begin{array}{l}-0.0786 \\
(-0.11)\end{array}$ & & $\begin{array}{l}0.3354 \\
(0.37)\end{array}$ \\
\hline $\mathrm{H}$ & & & & $\begin{array}{l}-18.5642 \\
(-0.20)\end{array}$ & $\begin{array}{l}-43.1225 \\
(-0.44)\end{array}$ \\
\hline N. obs & 703 & 703 & 703 & 703 & 703 \\
\hline N. groups & 84 & 84 & 84 & 84 & 84 \\
\hline Hansen test & 71.6 & 73.24 & 70.63 & 74.55 & 75.44 \\
\hline$p$-Value & 0.189 & 0.156 & 0.212 & 0.132 & 0.117 \\
\hline $\operatorname{AR}(1) p$-value & 0.004 & 0.007 & 0.004 & 0.004 & 0.006 \\
\hline $\operatorname{AR}(2) p$-value & 0.065 & 0.066 & 0.065 & 0.065 & 0.063 \\
\hline N. instruments & 70 & 71 & 71 & 71 & 73 \\
\hline LR multiplier & 2.49 & 2.29 & 2.50 & 2.48 & 2.28 \\
\hline
\end{tabular}
Time trend included, always insignificant. 
This variable allows to account for the relative costs per unit of produced good in each country in comparison to Western Europe. Because no other data is available, Austria is considered as representative for the western EU. Relative unit labor costs do not have any effect. Most likely, because the ULC seem to converge among countries and increase over time, as Akbar and McBride (2004) state. Specification (4) includes human capital of the whole labor force. We assume that MNCs prefer to invest in human capital rich countries. First, more advanced products can be created. Secondly, better educated workers are potential clients for the advanced goods that MNCs produce. However, it has no effect on FSFDI. All control variables are included in specification (5). The highly significant variables do not change in an important way.

The empirical results allow to conclude that the lagged FDIM, FSFDI interacted with dependence on external finance and the value added have a very strong and robust effect. This result is consistent with the determinants of bilateral FDI stocks at total economy level, studied in Section 2.

\subsection{The effect of FDI and FSFDI on domestic investment}

As shown above, FSFDI has a strong positive effect on FDI and we investigate whether it also has an effect on domestic investment. It is possible that foreign financial services improve the business climate and enhance investment. Investment is considered as a main source of economic growth. DeLong and Summers (1991) and Sala-i-Martin (1997) show that investment, especially in manufacturing and equipment, is a robust and highly significant factor of growth among many countries. This makes it an interesting question to see whether the presence of MNCs has any effect on domestic investment. For the countries which we consider there could be a strong positive effect because a large share of FDI is of horizontal nature and a lot of backward linkages exist (see Smarzynska Javorcik, 2004). On the other hand the more advanced MNCs can invest in the more profitable firms and thus crowd out domestic investment.

The long-run effect of foreign direct investment flows, loans and portfolio flows on gross capital formation in 60 Developing Countries over the period 1979-1999 is studied by Mody and Murshid (2005). In their study none of the Transition Economies which we consider is included. They find a very strong positive effect of FDI flows especially in the 1980's. Contrary, in the 1990's there is no significant effect. The authors conclude that the financial integration which appeared since the 1990s allowed domestic investors to diversify investment and invest also abroad.

Mileva (2008) applies their model to 22 Transition Economies over the period 1995-2005. She finds a very strong effect of FDI on investment, especially if the domestic financial market is underdeveloped. Mileva finds evidence for crowding-in of investment in the least developed Transition Economies, namely the former Soviet Republics. MNCs might buy input goods from local suppliers and motivate them to invest. However, for the EU member Transition Economies no positive effect on investment is found. She argues that most likely the more productive MNCs push the less developed local competitors out of the market.

Both studies mentioned above focus on investment on total economy level. We apply the regression to investment in manufacturing industries. In this case investment is very volatile and changes its direction depending on the current economic situation. The results on the aggregate level and disaggregated level can be expected to be substantially different. We include the lagged dependent variable, but expect it to be insignificant. We do so because of two reasons. First, we want to have results that are comparable to the recent literature. Secondly, the lagged domestic investment serves as a good instrument for the endogenous variables. There is no data about purely domestic investment, thus we calculate it. First, we take first differences of the FDIM stock to obtain flows (denoted FDIMFL). This procedure neglects the depreciation of capital, thus contains a small error. The FDIM flow is subtracted from the total investment to obtain domestic investment. Domestic investment is then divided by the number of workers in each industry (denoted DOMINVW). Total investment consists to around 70\% of domestic investment. To make sure that our results are not mainly affected by the way we calculate the variable, we repeat the regression with total investment in the manufacturing industries. The results do not change in a significant way. To analyze the effect of foreign financial services and FDI on domestic investment, we regress domestic investment per worker on the following variables:

$$
\begin{aligned}
& \Delta \text { DOMINVW }_{i j t}=\alpha \Delta \text { DOMINVW }_{i j t-1}+\beta_{1} \Delta \text { VAPW }_{i j t}+\beta_{2} \Delta \text { INFLATION }_{i t}
\end{aligned}
$$

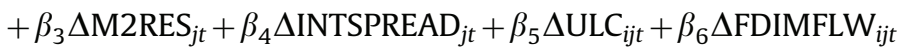

$$
\begin{aligned}
& +\beta_{7} \Delta \mathrm{FMKT}_{j t} \times \mathrm{DEF}_{i}+\beta_{8} \Delta \mathrm{FSFDIFLW}_{j t} \times \mathrm{DEF}_{i}+\Delta v_{i j t}
\end{aligned}
$$

The dependent variable DOMINVW is domestic investment per worker and can be considered a good proxy for the capital intensity in each industry. It is reasonable to assume that it depends on the value added. Thus, value added per worker VAPW is included. Analysis of both time series shows that the relationship between investment and value added on the industry level is much more volatile than it is on the macroeconomic level. ${ }^{12}$ Further on, the willingness to invest is affected by risk and the cost of capital, which is measured by INFLATION and interest rate spread INTSPREAD. Macroeconomic risk is also measured by the ratio of M2 money to reserves. The dependent variable measures the capital

\footnotetext{
12 For the considered countries, investment at economy level accounts for around 25\% of GDP annually, ranging from $15 \%$ to $39 \%$, with a variance of $5 \%$. In the manufacturing industries it accounts for $20 \%$ of value added on average, but it takes a very wide range, from $-350 \%$ to $150 \%$ with variance $25 \%$. This highly volatility indicates that domestic investment is crowded out by FDIM. MNCs buy large and productive firms, thus domestic investment sometimes becomes negative.
} 
intensity per worker in each industry. Capital and labor can be considered as substitutes. Unit labor costs (ULC) measure the cost of labor that is needed to produce one unit of output, relative to the whole manufacturing sector. ULC for the whole manufacturing sector is normalized to 100. This tells whether the labor input is more effective or less effective in given industries than it is on average. In general the unit labor costs are increasing, which might lead producers to substitute labor with capital. FDIMFLW denotes the flow of FDI in a sector of manufacturing in the host country, which is divided by the number of workers. The development of the financial market is measured as before and denoted FMKT. The better the financial market, the easier domestic firms can operate. It facilitates the creation of firms that produce intermediary goods, which gain from backward linkages. Further on, the FSFDI flow should have an effect on domestic investment. Because the inflow of FSFDI is used for investment purposes, a fraction should go to the manufacturing sector and increase domestic investment in it. The inflow of FSFDI per worker is denoted FSFDIFLW. As above, the dependance on external finance DEF is used to account for the impact of financial services and the financial market on different industries.

The specification is similar to that of Mody and Murshid (2005) and Mileva (2008). But unlike in their regression, we allow FDI and FSFDI flow to enter the regression with different coefficients. Moreover, we regress purely domestic investment. We consider this as an improvement because of two facts. First and foremost, the FDI and FSFDI flow per worker can have an enhancing effect on domestic investment, but their effect is expected to be different. Foreign banks make investment and business simple and MNCs can be an important business partner and a general source of technology and knowledge that might spill over to domestic firms. On the other hand, FDI can crowd out domestic investment. Secondly, gross capital formation is by construction the sum of domestic investment and FDI inflows. Thus, total investment and FDI inflow would be strongly correlated.

The regression results are presented in Table 5. In all specifications the regression can be considered as well specified. The number of instruments used is less than the number of groups. In all specifications the value added per worker enters with high significance. Neither inflation nor the interest rate spread enter significantly and also unit labor costs can be neglected. The baseline specification (1) shows that the flow of FDI has a very strong negative effect on domestic investment in manufacturing industries. The estimated coefficient does not differ significantly from -1 . This value is robust to any modification of the regression, thus it clearly shows that FDI crowds out domestic investment. In the same industry MNCs invest in the most profitable firms and leave the second best choice to the local competitors. One million \$ invested by a MNCs replaces one million $\$$ of domestic investment. Further on, growth of value added enforces domestic investment. An increase of value added by one million $\$$ leads to an increase of the investment flow by around 0.11 million. The development of the financial market alone does not play any role. In specification (2) the flow of foreign financial services per worker is included. It is interacted with the dependence on external finance DEF variable. The inflow of foreign financial services has no effect on domestic investment. This seems to be quite surprising, as one could expect that foreign

Table 5

Short-run determinants of domestic investment per worker in the manufacturing sector. Two-step difference GMM regression. $z$-Statistic in brackets, bold = significant at $5 \%$ level.

\begin{tabular}{|c|c|c|c|}
\hline Independent variables & $\begin{array}{l}\text { DOMINV } \\
(1)\end{array}$ & $\begin{array}{l}\text { DOMINV } \\
(2)\end{array}$ & $\begin{array}{l}\text { DOMINV } \\
(3)\end{array}$ \\
\hline DOMINVW_lag & $\begin{array}{l}-0.1098 \\
(-1.04)\end{array}$ & $\begin{array}{l}-0.1117 \\
(-1.01)\end{array}$ & $\begin{array}{l}-0.1115 \\
(-1.06)\end{array}$ \\
\hline VAPW & $\begin{array}{l}\mathbf{0 . 1 1 7 1} \\
(2.26)\end{array}$ & $\begin{array}{l}\mathbf{0 . 1 0 9 8} \\
(2.90)\end{array}$ & $\begin{array}{l}\mathbf{0 . 1 1 0 7} \\
(2.38)\end{array}$ \\
\hline INFLATION & $\begin{array}{l}-77.9181 \\
(-1.10)\end{array}$ & $\begin{array}{l}-68.0933 \\
(-0.94)\end{array}$ & $\begin{array}{l}-71.4540 \\
(-1.00)\end{array}$ \\
\hline M2RES & $\begin{array}{l}625.4967 \\
(1.17)\end{array}$ & $\begin{array}{l}596.7087 \\
(1.43)\end{array}$ & $\begin{array}{l}625.6508 \\
(1.16)\end{array}$ \\
\hline INTSPREAD & $\begin{array}{l}-268.5894 \\
-(1.46)\end{array}$ & $\begin{array}{l}-270.6855 \\
(-1.53)\end{array}$ & $\begin{array}{l}-266.4457 \\
(-1.50)\end{array}$ \\
\hline ULC & $\begin{array}{l}22.8838 \\
(0.89)\end{array}$ & $\begin{array}{l}21.7575 \\
(0.94)\end{array}$ & $\begin{array}{l}24.4710 \\
(0.87)\end{array}$ \\
\hline FDIMFLW & $\begin{array}{l}-\mathbf{1 . 1 3 7 5} \\
(-11.59)\end{array}$ & $\begin{array}{l}-\mathbf{1 . 1 3 9 2} \\
(-12.40)\end{array}$ & $\begin{array}{l}-\mathbf{1 . 1 3 7 3} \\
(-11.73)\end{array}$ \\
\hline FMKT $\times$ DEF & $\begin{array}{l}-33.0496 \\
(-0.40)\end{array}$ & & $\begin{array}{l}-30.6883 \\
(-0.36)\end{array}$ \\
\hline FSFDIFLW $\times$ DEF & & $\begin{array}{l}0.0162 \\
(0.55)\end{array}$ & $\begin{array}{l}0.0162 \\
(0.59)\end{array}$ \\
\hline N. obs & 561 & 561 & 561 \\
\hline N. groups & 82 & 82 & 82 \\
\hline Hansen test & 74.93 & 76.46 & 76.48 \\
\hline$p$-Value & 0.237 & 0.201 & 0.2 \\
\hline AR(1) $p$-value & 0.277 & 0.278 & 0.278 \\
\hline $\operatorname{AR}(2) p$-value & 0.235 & 0.233 & 0.23 \\
\hline N. instruments & 76 & 76 & 77 \\
\hline
\end{tabular}


banks facilitate access to credit and should enhance investment. In specification (3) the inflow of financial services FDI and the development of the financial market are included. The results do not differ from the previous ones. Again neither the development of the financial market nor the inflow of foreign financial services has any effect. It is quite troublesome to interpret this result. The literature presented at the beginning of this section shows that foreign banks improve the financial system and facilitate host firms access to credit. At the disaggregated level no effect is visible. As estimated in the previous section, financial services FDI enhances the remaining FDI. FDI picks the most productive investment objects and crowds out domestic investment. Consequently, less profitable objects remain for domestic investors. Maybe this explains why we cannot find any effect of foreign financial services on domestic investment. The indirect effect annihilates the direct effect.

We conclude that value added attracts domestic investors, FSFDI inflow has no effect and FDI inflow crowds out domestic investment.

\section{Concluding remarks}

This paper investigates the causes and effects of foreign direct investment in the financial and non-financial sector in Transition Economies. The empirical results allow to make three important statements. Non-financial FDI is positively affected by financial services FDI. Foreign banks in the EU Transition Economies are mainly driven by non-financial FDI and the capital intensity of a country. FDI inflow crowds out domestic investment in the manufacturing sector.

We tackle three important questions using one set of countries in approximately the same period of time. In the present literature those questions have been answered only partially and always in relation to different countries and very different time periods. Our study allows to draw a general conclusion. First and foremost, it is necessary to study the nexus between FDI, foreign financial services and domestic investment. Studies which look only at one direction of causality miss the mutual enforcement and the strong interaction between those very important economic variables. Secondly, it is important to apply a dynamic panel to capture the long-run relationship between the variables. GMM has to be applied whenever possible to tackle the endogeneity problem and the issue of hetersokedasticity and autocorrelation of the error term.

The main results of the estimations are as follows. First, at macroeconomic level, non-financial FDI stock that origins from different donor countries follows strongly its past period realization. This is a sign that FDI constitutes a permanent capital stock and is well integrated in the host economy. The current value is positively affected by the market potential and also by foreign financial services which give financial stability. The risk of a macroeconomic crisis has a strong detrimental effect. Secondly, we show that financial services FDI is strongly affected by non-financial FDI. This confirms the follow-the-client hypothesis. However, domestic investment plays a significant role and is an important determinant of FSFDI, too. Inflation affects the stock of FSFDI negatively. Thirdly, we investigate the nexus in the manufacturing sector. Like at aggregate level, the stock of FDI in each industry depends on its previous realization. Moreover, foreign financial services and the value added have a strong positive effect. Domestic investment has no effect on FDI. The stock market capital has a negative effect, which might indicate that FDI prefer weak economies in which they can exploit their comparative advantage. Further on, we find that domestic investment does not depend on its past realization. It is a flow, and depends on the value added. FDI flows have a strong negative effect and crowd out domestic investment.

Comparing our results with those from the recent literature we find that some results change drastically, conditional on the period and the sector of the economy that is considered. For example, recent studies at aggregate level show that foreign banks increase and stabilize the investment in the whole economy. However, in the manufacturing industries we do not find any effect of FSFDI on domestic investment. This shows that an economic variable can have different effects in different sectors of the economy and at different disaggregation levels. However, most of our results are in line with the empirical analysis presented in the literature. Our results should be interpreted with caution. The results apply to a period in which a high FDI inflow was observable. Nowadays, as the global financial crisis makes multinational corporations consolidate their capital in the home country, the effect might be very different. MNCs slow down their production or even stop it completely. Foreign banks withdraw funds and shift them to their home country. The economic impact of FDI might turn around. It was a major motor of economic growth, but due to the strong connection of the economies to the global economy it might have a detrimental effect during the next few years. This means that a new study which uses data since the middle of 2008 is necessary. However, we have to wait until the crisis is over and enough data is available to perform a new study. Moreover, the effect of FDI and foreign financial services on TFP and value added growth should be studied.

\section{Acknowledgment}

We thank Mario Padula for advice on econometrics and very useful ideas. Stefano Bosi provided us with very useful comments. Participants of the research seminar at the National Bank of Poland, at the Warsaw University, at the Warsaw School of Economics, the WISE seminar at the University of Venice, the International Risk Management Conference in Venice 2009 and the Warsaw International Economic Meeting 2009 provided useful comments.

The views expressed in this paper are those of the authors and do not necessarily reflect the opinions of the National Bank of Poland. 


\section{Appendix A. Data description}

The data sources and construction of the time series is presented here in detail. Data that is used in this paper origins from the Vienna Institute for International Studies (2008a), World Development Indicators (The World Bank, 2008), the Eurostat (2009) and OECD (2009). We observe some discrepancies in the data on the same variables from different sources. The reason might be different vintages of original data or different definitions of some variables. Whenever necessary, we compare data from different sources and use data which is consistent among most sources. All variables are transformed into international \$ at year 2000 constant prices. Data used in this paper is available upon request.

FDI, FSFDI-non-financial and financial services FDI stock in the host country. FDIM-non-financial FDI in the manufacturing industries. Data reported as stocks. Source: Vienna Institute for International Studies (2008a).

ULC - unit labor costs, RULC - relative unit labor costs to Austria. Source: OECD, Vienna Institute for International Studies (2008b).

GDP_Gross Domestic Product, GDPC_GDP divided by population, GDPW_GDP divided by labor force, INVW—gross capital formation, divided by labor force, DOMINVW-domestic investment, obtained by subtracting the FDI flow from total investment. Source: The World Bank (2008).

INFLATION, INTSPREAD — spread between lending and deposit interest rate, LENDINT_lending interest rate, REALINT_ real interest rate, FIXEDLINE_-number of fixed line and mobile phones per 1000 inhabitants, EDUCATED—share of labor force with secondary and tertiary education, EXPORTS, M2RES -M2 money over domestic reserves, GOVCONS - share of governmental consumption in GDP. Source: The World Bank (2008).

FMKT_financial market development, stock market plus credit to private sector divided by GDP, CDP_credit to private sector, divided by GDP, DCB — credit provided by banks, divided by GDP, STKMT—stock market capitalization divided by GDP, STMKTCAP_stock market capitalization. Source: The World Bank (2008).

RULC_relative unit labor costs. $\mathrm{RULC}_{i j t}=\mathrm{ULC}_{j t} / \mathrm{ULC}_{i t}, \quad \mathbf{R G D P}$-relative GDP size. $\mathrm{RGDP}_{i j t}=\ln (\mathrm{GDP})_{j t}-\ln (\mathrm{GDP})_{i t}$, $\mathbf{R K L}$-relative capital endowments, proxied by relative investment per worker. $\mathrm{RKL}_{i j t}=\ln (\mathrm{INVW})_{j t}-\ln (\mathrm{INVW})_{i t}$. $i$ denotes the host country, $j$ the donor country, $t$ is the time index.

HUMANCAP — schooling human capital per worker. I calculate human capital of workers with primary, secondary and tertiary education and then construct the average human capital using the following formula: $h_{t}=$ share $_{\text {prim }}$. $h_{t}^{\text {prim }}+$ share $_{s e c} \cdot h_{t}^{\text {sec }}+$ share $_{\text {tert }} \cdot e_{t}^{\text {tert }}$ with $h_{t}^{\text {prim }}=e^{\phi\left(s_{-} p r i m\right)}, h_{t}^{\text {sec }}=e^{\phi\left(s_{-} s e c\right)}$ and $h_{t}^{\text {tert }}=e^{\phi\left(s_{-} \text {tert }\right)}$. Here $s$ denotes years of schooling and $\phi(s)=0.13 * s$ for $s \leq 4, \phi(s)=0.13 * 4+0.1 *(s-4)$ for $4<s \leq 8$ and $\phi(s)=0.13 * 4+0.1 * 4+0.07 *(s-8)$ for $8<s$. Based on empirical observations, workers with primary education have 8 years of schooling, those with secondary 12 years and those with tertiary 16 years, on average. Original source for shares of labor force with different education levels is The World Bank (2008).

HM-human capital in manufacturing industries. First, human capital is constructed as above for the whole country. The human capital is multiplied by labor productivity in each industry. The productivity for the whole manufacturing sector of each country is normalized to 100 and origins from Vienna Institute for International Studies (2008a).

\section{Appendix B. Stata commands used}

\section{Bilateral FDI, Section 2}

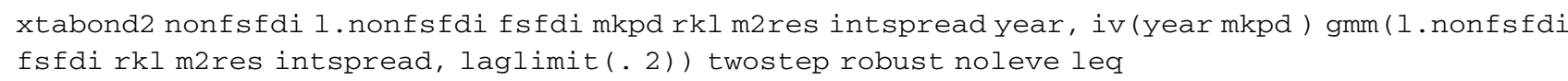

FSFDI, Section 3 xtivreg2 fsfdi l.fsfdi (nonfsfdi invtotal=1.nonfsfdi l.invtotal 1.gdp ulc exports) freedom
tax inflation m2res, fd small robust bw(4)

FDI in manufacturing, Section 4.1

xtabond2 fdim l.fdim fsfdidef va inv tax inflation m2res stockmktcapitaldef ulcra humancap year if country! = "Latvia", iv(year fsfdidef inflation m2res tax stockmktcapitaldef ulcra humancap) gmm( (1.fdim va inv), lag(. 2)) twostep robust noleveleq

\section{Domestic investment, Section 4.2}

xtabond2 dominvw 1 . dominvw vapw inflation intspread ulc m2res fdimdifw financemktdef fsfdidifwdef year if country!="Latvia", iv (year inflation intspread m2res financemktdef fsfdidifwdef ) gmm ( ( 1. dominvw vapw fdimdifw ulc), $\operatorname{lag}(.2))$ twostep robust noleveleq

\section{References}

Akbar, Y., McBride, J., 2004. Multinational enterprise strategy, foreign direct investment and economic development: the case of the Hungarian banking industry. Journal of World Business 39, 89-105. 
Alfaro, L., Chanda, A., Kalemli-Ozcan, S., Sayek, S., 2004. FDI and economic growth: the role of local financial markets. Journal of International Economics $64,89-112$.

Arellano, M., Bond, S., 1991. Some tests of specification for panel data: Monte Carlo evidence and an application to employment equations. The Review of Economic Studies 58 (2), 277-297.

Barrell, R., Pain, N., 1996. An econometric analysis of U.S. foreign direct investment. The Review of Economics and Statistics 78 (2), $200-207$.

Baum, C., 2006. An Introduction to Modern Econometrics Using Stata. Stata Press.

Bevan, A., Estrin, S., 2004. The determinants of foreign direct investment into european transition economies. Journal of Comparative Economics 32, $775-787$.

Borensztein, E., De Gregorio, J., Lee, J.W., 1998. How does FDI affect economic growth? Journal of International Economics 45, $115-135$.

Buch, C.M., 1997. Opening up for foreign banks: how Central and Eastern Europe can benefit. Economics of Transition 5 (2), 339-366.

Buch, C.M., 2000. Why do banks go abroad? Evidence from german data. Financial Markets, Institutions \& Instruments 9 (1), $33-67$.

Carstensen, K., Toubal, F., 2004. Foreign direct investment in Central and Eastern European countries: a dynamic panel analysis. Journal of Comparative Economics 32, 3-22.

DeLong, B.J., Summers, L.H., 1991. Equipment investment and economic growth. Quarterly Journal of Economics 106, 445-502.

Eller, M., Haiss, P., Steiner, K., 2006. Foreign direct investment in the financial sector and economic growth in Central and Eastern Europe: the crucial role of the efficiency channel. Emerging Markets Review 7, 300-319.

Eurostat, 2009 〈http://ec.europa.eu/eurostat/〉.

Goldberg, L.G., Johnson, D., 1990. The determinants of US banking activity abroad. Journal of International Money and Finance 9, $123-137$.

Guiso, L., Jappelli, T., Padula, M., Pagano, M., 2004. Financial market integration and economic growth in the EU. Economic Policy $40,523-577$.

Heritage Foundation, 2009. 2009 Index of Economic Freedom. Washington, DC.

Jeanneau, S., Micu, M., 2002. Determinants of International Bank Lending to Emerging Market Countries. BIS Working Papers No 112.

Mérö, K., Valentinyi, M., 2003. The Role of Foreign Banks in Five Central and Eastern European Countries. Hungarian Central Bank Working Paper 10.

Mileva, E., 2008. The Impact of Capital Flows on Domestic Investment in Transition Economies. Working Paper 871. European Central Bank.

Mody, A., Murshid, A.P., 2005. Growing up with capital flows. Journal of International Economics 65, $249-266$.

Mody, A., Taylor, M.P., Kim, J.Y., 2001. Modelling fundamentals for forecasting capital flows to emerging markets. International Journal of Finance and Economics 6, 201-216.

Neuhaus, M., 2006. The Impact of FDI on Economic Growth: An Analysis for the Transition Countries of Central and Eastern Europe. Physica-Verlag, Heidelberg.

OECD, 2009. Organisation for Economic Development and Cooperation (OECD). 〈http://www.oecd.org/statsportal $\rangle$.

Rajan, R.G., Zingales, L., 1998. Financial dependence and growth. American Economic Review 80 (3), 559-586.

Roodman, D., 2006. How to Do xtabond2: An Introduction to "Difference" and "System" GMM in Stata. Working Paper 103. Center for Global Development, Washington.

Sala-i-Martin, X., 1997. I just ran two million regressions. American Economic Review, Papers and Proceedings 87, $183-197$.

Schaffer, M.E., 2007. xtivreg2: Stata Module to Perform Extended IV/2SLS, GMM and AC/HAC, LIML and $k$-Class Regression for Panel Data Models.

Smarzynska Javorcik, B., 2004. Does foreign direct investment increase the productivity of domestic firms? In search of spillovers through backward linkages. The American Economic Review 94 (3), 605-627.

The World Bank, 2008. World Development Indicators. The World Bank Group, Washington.

Vienna Institute for International Studies, 2008a. wiiw Database on Foreign Direct Investment in Central, East and Southeast Europe. Vienna.

Vienna Institute for International Studies, 2008b. wiiw Industrial Database Eastern Europe. Vienna.

Weill, L., 2003. Banking efficiency in transition economies: the role of foreign ownership. The Economics of Transition 11 (3), $569-592$.

Wezel, T., 2004. Foreign Bank Entry Into Emerging Economies: An Empirical Assessment of the Determinants and Risks Predicated on German FDI Data. Deutsche Bundesbank Discussion Series 01. 